\title{
Lessons Learned by Organisations during the COVID-19 Pandemic
}

André de Waal, HPO Center, the Netherlands

Julie Linthorst

HPO Center, the Netherlands

\author{
Caroline Hetterschijt \\ Deusto Universidad, Spain
}

\begin{abstract}
The COVID-19 caught many organisations off guard. The same is true for the academic 'future of work' literature, which hardly pays any attention to a disruptor like a pandemic. In the past months a catching up in the academic and especially the professional literature regarding COVID-19 could be noticed. However, this literature does not describe the actual actions organisations take to deal with the implications of COVID-19. In this article, based on a literature review a classification scheme of possible actions is drafted. Subsequently, 19 European organisations were interviewed and the actions they are undertaking are put in this classification scheme. In addition, the positive outcomes of these actions are collected as are the lessons learned by the organisations in these past months. The research results help further academic research in mapping the implications of and actions to combat disruptors like pandemics. They also help organisations prepare themselves better for the inevitable next crisis.
\end{abstract}

Keywords: COVID-19; Organizational Consequences; Organizational Actions; Lessons Learned; Impact on Business 


\section{Introduction}

To state that the COVID-19 pandemic has a great impact on the business community is an understatement (Hughes et al., 2020; Kniffin et al., 2020; Shankar, 2020). Some authors even state that this pandemic is creating an economic crisis that is bigger and thus will have more impact than the financial crisis of 2008 (Cassidy, 2020; IMF, 2020). According to the Society for Human Resource Management (SHRM) (2020), based on a survey of more than $2000 \mathrm{HR}$ professionals, one-third of the employers where these surveyed professionals worked had no emergency preparedness plans to deal with similar disasters, and of the two-third that had a plan more than half did not include policies covering communicable diseases. Over 7 in 10 employers were struggling to adapt to remote working, 2 in 3 employers reported that they had difficulty maintaining morale amongst their employees, and over a third of employers were struggling with decreasing productivity. The pandemic forced 40 percent of the organisations to shut down certain aspects of their business operations, with another 19 percent contemplating to do the same, and 10 percent even facing a total shutdown. In total 83 percent of the organisations had to adapt their business practices to the new situation (i.e. no more new hires, decreased hours and/or pay rates for employees, layoffs, offering paid or unpaid leave), with another 8 percent considering doing the same. Similar disturbing figures are reported by other sources, such as Beech and Anseel (2020), Eggers (2020), Kniffin et al. (2020), and Wang et al. (2020). To make matters worse, organisations rarely allocate enough resources to prepare for, let alone deal with crises such as pandemics (Bowers et al., 2017; Burkle, 2010; McMenamin, 2009).

This situation is already popularly called 'the new normal', which is described by Verbeke (2020, p. 444) as "a situation of radical change, consistent with a large exogenous shock experienced by firms and society at large. Such shock can be a radical change in institutions or a broader-environment related shock. Through many cascading effects, somewhat like those found in ecological systems, the shock structurally changes behaviours". This 'new normal' forces organisations to adjust their business operations to fit the new situation. Unfortunately, the academic literature does not provide much in the form of effective guidelines and ideas for dealing with this type of new situation caused by COVID-19. There is some economic epidemiology research that provides insights into the relationship between (potential) influenza pandemic events, the behavioural responses of people to outbreaks, and the economic consequences of these responses and the disease (Brahmbhatt and Dutta, 2008; Geoffard and Philipson 1996; Gersovitz and Hammer 2004) but no information can be found in relation to the topic of 'future of work'. This is illustrated by the results of research undertaken by Linthorst and de Waal (2020). Their research consisted of a descriptive literature review with the aim to identify the megatrends and disruptors that academic researchers predicted would potentially become important to deal with for organisations in their workplace in the (near) future.

The initial review of the so-called 'future of work' academic literature hardly yielded megatrends or disruptors so they had to turn to the professional managerial literature. Ultimately, the researchers were able to identify thirteen megatrends and one disruptor and the impact these (potentially) have on organisations. In this respect, megatrends are described as large social, economic, political, and technological changes that are

International Journal of Management and Applied Research, 2021, Vol. 8, No. 1 
slow to form, and once in place, they have an influence for some time, between seven or ten years, or longer (Naisbitt and Aburdene, 1990). Disruptors are defined as 'someone or something that prevents something, especially a system, process or event, from continuing as usual or as expected' (Cambridge Dictionary, 2020). The main difference between megatrends and disruptors is the speed with which they appear and the effects they have, i.e. megatrends are changes that (often gradually) take place over a longer period of time, while disruptors are short-term, seemingly unexpected sharp changes with high impact (de Waal and Linthorst, 2020). The one disruptor Linthorst and de Waal found in just a small percentage of the examined literature was the pandemic, which is the worldwide spread of an infectious disease (such as the 1918 Spanish flue, HIV/AIDS and currently COVID-19). In their literature review de Waal and Linthorst hardly found any ideas for organisations to effectively deal with the implications of pandemics. This basically means that a lot of organisations have "to make it up as they go."

To help these organisations on their way, we undertook discovery-oriented research into what organisations are currently doing to combat the COVID-19 implications. Our research aimed to find answers to the research question: How are organisations in practice dealing with COVID-19 in their work environment and business processes? For this, we first developed a theoretical categorisation scheme, based on a review of the literature on the implications of COVID-19 as foreseen by researchers at the time of our study. Subsequently we collected case studies of organisations dealing, in their own words, effectively with the COVID-19 implications. Our findings were entered into the categorisation scheme and from this we derived several main ways of working that currently seem to be among the best ideas to deal with the COVID-19 organisational implications. Learning in this way from what organisations did, and are doing, in practice to deal with COVID-19 gives us the opportunity to learn from disaster, increase our knowledge to deal with disruptors, and foster new more efficient and effective ways of working (Herlant, 2020). As such, the study result will help organisations and their managers to deal more effectively with the crisis and economic recession and thus mitigate the negative effects of COVID-19. Our study also helps further the theory on disruptors, and specifically pandemics, as we fill the current gap in the literature on how to deal effectively with the organisational implications from such a pandemic in an evidence-based manner. Although pandemics were not paid much attention to in the future of work academic literature, the recent COVID-19 outbreak shows that they do have a great and pervasive impact on societies and organisations and thus should be paid much more attention to (de Waal and Linthorst, 2020; Kniffin et al., 2020).

The remainder of this article is structured as follows. In the next section, the literature on the implications that the COVID-19 pandemic has for organisations and their operations is examined, these implications form the basis for a classification scheme to be used in the practical research. This is followed by a description of the research approach we used. Subsequently the research findings are described and discussed. The article ends with a conclusion, the limitations to our study, and opportunities for future research.

International Journal of Management and Applied Research, 2021, Vol. 8, No. 1 


\section{COVID-19 in the literature}

As mentioned before, up until 2020 there was not much literature to be found which discussed pandemics from an organisational angle, i.e. which implications a pandemic would have for organisations and how they could and should deal with or prepare for a (next) pandemic (de Waal \& Linthorst, 2020; Linthorst and de Waal, 2020). This gap in the academic organisational literature is quickly being filled since the emergence of COVID-19 at the beginning of 2020. An increasing number of academic papers are dedicated to the implications COVID-19 will have for organisations and their business operations. These implications, which can be seen as areas where organisations will have to take action, can be summarised as follows.

- Accelerate the digital transformation. The social distancing measurement has caused a big shift from brick and mortar to online operations, and many organisations have digitalized their operations as much as possible. This change is also in response to changing consumers' demands and purchasing behaviours. It is accompanied by an acceleration of the shift to (mandatory) 'work from home' and the use of 'virtual teams' with team members which can be scattered around the globe (Kniffin et al., 2020; McConnell, 2020; Watson et al., 2020).

- Focus on increased communication and dialogue, with remote leadership. Employees working at home and not in the office ask for (more) virtual leadership from managers who are much less in physical contact with their team members. Remote working also asks for more communication and dialogue, mainly through applications such as skype, Microsoft teams and zoom, in order for employees and managers to stay in touch with each other and to keep the company feeling (Cortez and Johnston, 2020; Grint, 2020; He and Harris, 2020; Kniffin et al., 2020; Tourish, 2020).

- Put more emphasis on corporate social responsibility. Consumers are increasingly addressing organisations about the negative effects of their products and services on the quality of life and the environment, and expect them to take, in the wake of the pandemic, more measures to combat issues as global warming, deterioration of the natural environment, and income inequality (He and Harris, 2020; Kniffin et al., 2020; Liu et al., 2020; Watson et al., 2020).

- Create a greater organisational capacity for resilience and responsiveness. The emphasis on efficiency of the past decades has been detrimental for the capacity of organisations to react quickly and effectively on the COVID-19 pandemic. Thus, people expect organisations to pay more attention to resilience in their products and product lines (for example in food supply with plant-based meat replacements), and to create slack in their business operations so there is capacity to deal with unexpected events (Shankar, 2020; Watson et al., 2020).

- Rethink the future of the organisation. Many organisations are going to rethink their focus and role in society; what kind of organisation they want to be for their clients, stakeholders and employees; how they want to service these in the future with what kind of (societally acceptable) products; and from whom to source their raw materials (among other questions) (Beech and Anseel, 2020; Brammer and Clark, 2020; Shankar, 2020).

International Journal of Management and Applied Research, 2021, Vol. 8, No. 1 
- Strengthen collaboration across organisational and industry borders. Organisations have learned during the pandemic that they depend hugely on each other and that, at the same time, many collaborations were not on-par. Organisations will spend more time and effort on interdisciplinary research and collaboration, to solve problems quicker and more effectively. This will increase the speed of decision-making and action-taking with a lot less bureaucracy than 'in the old days'. This strengthening will be associated with a rethinking of with which suppliers the organisation will strengthen collaborations and from which suppliers the organisation will take its leave (Beech and Anseel, 2020; Herlant, 2020; Liu et al., 2020; He and Harris, 2020; Shankar, 2020; Verbeke, 2020).

Linthorst and de Waal (2020) did not find many practical actions described in the academic literature how organisations can deal with the aforementioned implications of COVID-19. This unfortunately also applies to most of the recent 2020 literature. An explanation for this could be that academic literature in general lags behind organisational practice and has not yet caught up to the concrete actions organisations are taking to deal with COVID-19. We therefore turned to the professional managerial literature at it seems to be more "on top of things", probably because consultants and professional associations are able to quickly mobilise their clients and members to conduct research with (Jacobson et al., 2005; Kakabadse et al., 2006; Mahlendorf, 2014). This research is often in the form of questionnaires and interviews. Looking at the professional literature, some of the tangible actions organisations are or should be taking according to the clients of mainly consultancy firms, did overlap with those mentioned in the academic literature. But as there were quite a few actions described in the professional literature which were not mentioned in the academic literature, we decided to include these actions in the classification scheme:

- Rebuild operations to become more nimble as organisation. Organisations should focus on getting operations up-and-running as quickly as possible so clients can be serviced adequately and revenue start coming in again. This means they should look at the quality of their end-to-end delivery processes and possibilities to make these more resilient, agile and automated. They should also evaluate their current capitaland operating expenses and make changes in these, if needed. It also entails more delegation and empowerment to lower levels to speed up decision making and increase execution excellence, flattening the organisational structure, employing nimble and empowered teams, using more hybrid ways of working (e.g. remote and in-house), working more closely with partners, and installing new leadership fit for working in this environment (Cortez and Johnston, 2020; de Smet et al., 2020; Eager et al., 2020; Emmett et al., 2020; Herlant, 2020; Luijs et al., 2020; Shih, 2020).

- Pay (more) attention to the people in the organisation during times of stress. Organisations have to take the time to recognise how people in the organisation feel and how they hold up under the pressure caused by COVID-19, and then take appropriate measures to help and support them (Cortez and Johnston, 2020; Eager et al., 2020; Emmett et al., 2020; Herlant, 2020; Levy et al., 2020).

International Journal of Management and Applied Research, 2021, Vol. 8, No. 1 
- Develop remote working. The old ways of working, i.e. being physically present in the office or factory, will not (fully) come back, so organisations have to organize for efficiency in regard to people working at home, dealing with a more distributed workforce and virtual teams, and fostering best practices around collaboration, flexibility, inclusion, and accountability (Kniffin et al., 2020; McConnell, 2020).

- Transition to an organisation based on networks and teamwork. Traditional organisational structures will become less important and will be even broken down, in favour of an open work environment with speedy decision-making and actiontaking with a big focus on organisational agility and resilience (Levy et al., 2020; Saliola and Islam, 2020; Luijs et al., 2020).

- Change the sourcing process to be less dependent on a limited number of suppliers. Supply chains that have been optimised to just-in-time and cost efficiency have proven to be too vulnerable. So, organisations need to redesign their supply chains, especially for critical materials, to better guarantee availability by for instance sourcing more locally (Eager et al., 2020; Herlant, 2020; Shih, 2020).

- Focus on the long-term sustainability of the organisation. Organisations need to focus more on the long-term survival of the company and the long-term servicing of stakeholders. They can do this by no longer giving out quarterly earnings estimates, more collaboration with clients, partners, legislators and government to create a better future, and invest more in environmental measures (Eager et al., 2020; Levy et al., 2020; Shih, 2020).

- Invest (even) more in IT. The advent of the contact-free economy has accelerated significantly during the COVID-19 crisis, so organisations need to (re)design themselves for this type of economy. This entails at many organisations the acceleration of (further) digitilisation and automation. They also need to refocus current digital efforts to reflect changing customer expectations; and increase the application of data, Internet of Things, and AI to better manage operations (Cortez and Johnston, 2020; Emmett et al., 2020; Shih, 2020; McConnell, 2020).

- Rethink the purpose and mode of operation of the organisation. It is no use to aim for returning to normal after the pandemic as the new normal will (at least for a good part) become the normal. So, organisations need to ponder questions such as: who we are, how do we (want to) work, how do we want to grow (Emmett et al., 2020; Herlant, 2020; Jacobides and Reeves, 2020; Levy et al., 2020; McConnell, 2020).

- Understand organisational risks better, in a more holistic manner. Organisations need to develop a better understanding of the risks (not only from pandemics) that threaten them, ways how to deal with these and the requirements needed for this. This should be done by regular and structural environmental scanning, scenario planning, stress-testing of business continuity plans and operating models, more dynamics in risk management in the sense of better sensing and reacting to signals from internal operations and external supply chains and the environment (Eager et al., 2020; Herlant, 2020; Jacobides and Reeves, 2020).

When studying the organisational responses to the COVID-19 pandemic as identified from both the academic and professional literature it must be noted that these actions

International Journal of Management and Applied Research, 2021, Vol. 8, No. 1 
appear to be mainly intended actions. That is to say, these actions were mainly collected through interviews in which the interviewees were asked what they were planning to do or thought were good ideas to deal with the COVID-19 implications. No assessment has taken place yet whether organisations actually undertook these intended actions in practice and how effective these actions turned out to be. We aim to fill this gap in the literature by researching what organisations actually did, by interviewing managers on what their organisations actually are doing in this COVID19 period, as described in the next section.

\section{Research approach}

To find an answer on our research question How are organisations in practice dealing with COVID-19 in their work environment and business processes? we used a discovery-oriented grounded theory approach for our research (Corbin and Strauss, 2014). We determined that this approach was the most suitable for several reasons. The literature with which to address our research question was scant; the chosen approach permitted us to capture real-time observations and information on a phenomenon that was currently happening; and the approach allowed us to be active in understanding and extending what we would obtain from our case study organisations (Cortez and Johnston, 2020).

We decided to approach managers in our network and ask them if they would like to cooperate in our research on the effects of COVID-19 on their organisations and what measures they were currently taking to combat the implications of the pandemic. In this respect, our research population was basically a convenience sample as we were dependent on the willingness of people in our network to be part of the research. At the same time, in order to quickly gather information during the time the phenomenon of COVID-19 took place this approach was the most practical one. We decided to focus on companies in our network to make sure the research was manageable in the relative short research time we had (two months). We approached 19 managers, one per organisation, and these all agreed to participate. Before the interviews we send the managers the set of questions we were going to ask them:

- How do you describe the impact of COVID-19 crisis on your organisation?

- What actions did you undertake during, and as a consequence of the COVID-19 crisis?

- What do you consider as positive outcomes of the COVID-19 crisis for your organisation?

- What lessons have you learned from the COVID-19 crisis for the future?

Our research was aimed to hear from the managers without giving them a prescribed list of possible actions. In this way we learned what was important to them without influencing them with ideas from other people. The case study organisations were promised anonymity so answers could not be traced back to specific companies. Table 1 provides information on the participating organisations.

Table 1: Information on the participating organisations

\begin{tabular}{llc}
\hline Information & Detail & Number \\
\hline Country & Netherlands & 13 \\
& Spain & 4
\end{tabular}

International Journal of Management and Applied Research, 2021, Vol. 8, No. 1 


\begin{tabular}{lll}
\multirow{4}{*}{ Industry } & UK & 2 \\
& Education & 1 \\
& Food & 2 \\
& European Agency & 1 \\
& Healthcare & 3 \\
& ICT & 3 \\
& OEM & 1 \\
& Media & 1 \\
& Automotive & 2 \\
& Engineering & 1 \\
& Manufacturing & 1 \\
& Real Estate & 2 \\
Size (No. of employees) & R\&D & 1 \\
& $1-100$ & 6 \\
& $101-500$ & 3 \\
& $501-1000$ & 5 \\
& more than 1000 & 5 \\
\hline
\end{tabular}

The interviews by phone lasted in general between 30 and 45 minutes and the answers of the managers were during the interviews directly transcribed in a standard case study form. In a limited number of cases a manager filled in the interview questions beforehand and we then talked about these answers. Subsequently, the lead author processed all forms by combining the various answers from the managers into categories and putting these in a matrix which was derived from the literature review. This matrix can be found in Appendix 1. After this, the two other authors reviewed the matrix to make adjustments and corrections. The finalised matrix formed the basis of the analysis as described in the next section.

\section{Research results and analysis}

\subsection{Impact of COVID-19}

The first question we asked was about the impact of COVID-19 on the organisation. Regarding the financial consequences, it turned out that 37 percent experienced negative financial consequences, 21 percent experienced positive financial consequences, and 42 percent said the financial consequences were neither (too) negative nor (too) positive. This outcome seems in contradiction with general opinion, as formulated at the beginning of this article, that the financial consequences of this pandemic will potentially be bigger than those of the financial crisis of 2008 (Cassidy, 2020; IMF, 2020). A reason for this could be that at the time of our research (July 2020) the full implications of the crisis were not apparent yet. Certainly in the case of Dutch organisations (which form the majority of our research population) this could be the case as they at that time still enjoyed government support in the form of interestfree loans and salary support for their employees (Business.gov.nl, 2020). It could thus very well be that our research result in this respect might become more negative. On the other hand, there are several organisations in our research population that actually prosper during this COVID-19 period as there is particularly high demand for their products and services during these trying times, i.e. food producing and ICT (see for information McConnell, 2020; Statistics Netherlands, 2020).

International Journal of Management and Applied Research, 2021, Vol. 8, No. 1 


\subsection{Actions to combat COVID-19}

While categorising actions taken by the organisations to deal with COVID-19 the actions as found in the academic and professional literature proved to be a useful classification scheme. Table 2 provides a summary of the categorisation of the main actions, ordered in decreasing number of participating organisations applying the action. Appendix 1 provides more detail regarding specific actions per main action category.

Table 2: Theoretical and practical COVID-19 actions taken by European organisations

\begin{tabular}{|c|c|c|c|}
\hline Main actions & $\begin{array}{l}\text { Academic } \\
\text { literature }\end{array}$ & $\begin{array}{l}\text { Professional } \\
\text { literature }\end{array}$ & $\begin{array}{c}\text { Number of } \\
\text { organisations } \\
\text { take action }\end{array}$ \\
\hline $\begin{array}{l}\text { 1. Develop effective remote } \\
\text { working/WFH }\end{array}$ & & $X$ & 18 \\
\hline $\begin{array}{l}\text { 2. Pay (more) attention to the people in } \\
\text { the organisation }\end{array}$ & & $\mathrm{X}$ & 15 \\
\hline $\begin{array}{l}\text { 3. Stay in close contact with customers } \\
\text { and partners }\end{array}$ & & & 15 \\
\hline $\begin{array}{l}\text { Focus on increased communication } \\
\text { and dialogue, with remote leadership }\end{array}$ & $\mathrm{X}$ & & 12 \\
\hline $\begin{array}{l}\text { 5. Rebuild operations speedily and } \\
\text { with more speed }\end{array}$ & & $\mathrm{X}$ & 11 \\
\hline 6. Take financial measures & & & 8 \\
\hline $\begin{array}{l}\text { 7. Accelerate digital transformation } \\
\text { /Invest more in IT }\end{array}$ & $\mathrm{X}$ & $\mathrm{X}$ & 6 \\
\hline $\begin{array}{l}\text { 8. Create a greater organisational } \\
\text { capacity for resilience and } \\
\text { responsiveness }\end{array}$ & $\mathrm{X}$ & & 4 \\
\hline $\begin{array}{l}\text { 9. Rethink the future of the } \\
\text { organisation (incl. long-term focus + } \\
\text { risk management) }\end{array}$ & $X$ & $X$ & 4 \\
\hline $\begin{array}{l}\text { 10. Strengthen collaboration / Transfer } \\
\text { to networks \& teamwork }\end{array}$ & $\mathrm{X}$ & $\mathrm{x}$ & 4 \\
\hline Change the sourcing process & & $X$ & 2 \\
\hline $\begin{array}{l}\text { 12. Put more emphasis on social } \\
\text { responsibility }\end{array}$ & $\mathrm{X}$ & & 0 \\
\hline
\end{tabular}

In Table 2 for each action it is stated whether it was found in the academic or/and professional literature. Interestingly there are two main actions which are not described in either type of literature: '3. Stay in close contact with customers and partners' and '6. Take financial measures'. The main actions as described in the literature seem to mainly focus on the organisation itself and its people which need to be put in order again. The financial aspect, both regarding financial costs and financial income, is lost sight of in the literature which is a real shortcoming as especially the financial income side (i.e. 'stay in close contact with customers and partners') is rated in the Top 3 of actions taken. It seems that the participating organisations are fully aware that they exist to serve their clients and that they do their utmost to keep doing that, even or particularly in these difficult times (Yost and Cheng, 2021).

On the other hand, it is also interesting that the literature predicts more emphasis on social responsibility (action 10) while in reality organisations are not (yet) committed 
to it. It could very well be that this action is one for the longer term. In fact, when Table 2 is viewed from a time angle, it seems that actions 1 to 7 are short-term in nature. They are aimed at making sure the operation keeps functioning in good order by making sure that employees can keep doing their work as good and as bad as they can so that customers can continue to be serviced. Actions 8 to 12 seem to be of a longer-term nature where (possibly) fundamental changes of the organisation and its modus operandi might be undertaken. One more interesting finding which comes from Appendix 1 is that only two of the 19 participating organisations were prepared for a pandemic crisis. This is only 11 percent of the organisations, a percentage which underlines the earlier finding of Linthorst and de Waal (2020) that organisations in general do not seem prepared for the implications of megatrends and especially disruptors.

\subsection{Positive outcomes and lessons learned}

Every challenge provides an opportunity, as Table 3 shows. In this table the main positive outcomes of the COVID-19 actions taken by organisations are listed.

Table 3: Positive outcomes of the COVID-19 actions taken

\begin{tabular}{lc}
\hline Positive outcomes of COVID-19 for the organisation & $\begin{array}{c}\text { Number of } \\
\text { times } \\
\text { mentioned }\end{array}$ \\
\hline $\begin{array}{l}\text { Working from home is viable } \\
\text { People showing more solidarity/commitment/collaboration with each other }\end{array}$ & $\begin{array}{l}10 \\
\text { Increased speed/flexibility/decisiveness/efficiency of work }\end{array}$ \\
$\begin{array}{l}\text { Breaching of organisational hierarchy and willingness to change old working } \\
\text { patterns }\end{array}$ & 7 \\
More trust of managers in employees and vice versa & 6 \\
$\begin{array}{l}\text { Opportunity to work on ecological measures (f.i. less car travel) } \\
\text { Strengthening of the innovative culture / opportunity to develop new products }\end{array}$ & 6 \\
and services & 6 \\
$\begin{array}{l}\text { People becoming more self-sufficient/efficient, taking accountability, having a } \\
\text { can-do attitude }\end{array}$ & 5 \\
$\begin{array}{l}\text { Development of the right mindset for 'the new normal' becoming the normal } \\
\text { More attention for and thinking about the 'bigger picture' and future of the }\end{array}$ & 3 \\
$\begin{array}{l}\text { organisation } \\
\text { Better and more integrated communication in the organisation }\end{array}$ & 3 \\
Strengthened relations with clients and partners & 2 \\
\hline
\end{tabular}

Table 3 illustrates a saying nowadays often heard that "we have finally reached what we for years have been striving for" such as more working from home, a workforce more open to change, people trusting each other more and willing to collaborate more, and establishing a real innovative culture. These have all been persistent issues in organisations and topics of many academic and professional articles. Table 3 provides a nice array of 'benefits' but focuses us now on the question: "How are we going to make these benefits a permanent feature of the organisation, how can we make sure these changes will endure?"

In Table 4 the lessons learned so far from the COVID-19 as mentioned by the participating organisations are listed. Interestingly, these are lessons learned when we

International Journal of Management and Applied Research, 2021, Vol. 8, No. 1 
asked the managers specifically what they have learned: some interviewees recalled that they were now for the first time thinking of these lessons learned.

Table 4: Lessons learned so far from the COVID-19 crisis

\begin{tabular}{lc}
\hline Lessons learned & $\begin{array}{c}\text { Number of } \\
\text { times } \\
\text { mentioned }\end{array}$ \\
\hline Blended processes (e.g. in-house + remote) are also effective & 7 \\
Forget yearly targets and plans, survival and agility of the organisation is most & 5 \\
important & 5 \\
Make sure the organisation is agile enough to easily adapt to changes & 5 \\
Understand the IT architecture and its possibilities/functionality & 3 \\
Communicate, communicate, communicate & 3 \\
Need for employee involvement is an important drive for creative solutions & 2 \\
Quickly develop new policies on the way the organisation is going to work & 2 \\
Virtual communication shortens lines and increases quality of communication & 2 \\
Sense of urgency makes things possible, so after COVID-19 keep creating & 2 \\
this sense & 2 \\
Tailor organisational policies/procedures/resources more to the individual's & 1 \\
situation & 1 \\
Have an eye for the issues regarding working from home (f.i. work/life & 1 \\
balance, social aspects) & 2 \\
Be prepared for a crisis ("fail to plan is plan to fail") & 1 \\
Keep giving each other compliments & 1 \\
Maintain a highly visible leadership style & Watch out as management to get too much bogged down in operations at the \\
expense of strategy & 1 \\
\hline
\end{tabular}

\section{Conclusion, limitations and future research}

As Table 4 shows the participating organisations have had quite a few different experiences as there are 16 different lessons learned from which only a handful overlap. This might be because we had quite a wide expanse of participating organisations with different sizes and originating from three countries and operating in twelve different industries. What is the common thread that becomes visible when we look at all the courses described? That is according to us that during a crisis it is especially important to keep listening to the employees and to support them. Pay the utmost care to the physical and mental health of employees, so that they can keep working even under difficult circumstances. As a manager, make sure you are always contactable and available. Listen to what the employees have to say, both in private conversations and virtual sessions. Follow up on what employees tell you and involve them in developing solutions. Set challenging goals even in difficult times, but make sure that the employees will not get overloaded and burn-out. Show your human side; no one is infallible. We dare to assert that adhering to these 'tips' will result in excellent performance even during a pandemic.

Because of our experience gained during the COVID-19 pandemic, we now know better how we must act in the event of the next pandemic. But let's not make the mistake of thinking we're already "there" with the lessons learned. Now it is time to think ahead, which is needed because as a result of the pandemic we can expect new

International Journal of Management and Applied Research, 2021, Vol. 8, No. 1 
problems. Has there already been thought about what these will be, such as how to deal with the increasing number of employees/customers/suppliers who are in financial problems? Or, how to deal with employees/customers/suppliers who struggle with (long-term) health problems as a result of COVID? In addition, organisations need to better prepare themselves for other disruptors (such as environmental disasters or IT hacks), and implement a dynamic futurize process - that is, a process in which an organisation dynamically prepares for the future - to develop a mindset in the organisation involving thinking ahead: everyone has to be forward thinking ánd proactive (instead of reactive, as was the case with COVID-19).

In conclusion, we achieved our aim of answering the research question How are organisations in practice dealing with COVID-19 in their work environment and business processes? in respect of giving a first overview what actions organisations (in Europe) take to deal with COVID-19 and what the different lessons they have learned along the way are. With only 19 organisations in our research population we do not claim to give the full picture of what is happening currently in Europe, let alone the world. But we do think we were able to give a first impression, an impression which has not fully been developed yet in the academic nor in the professional literature. As such, we hope to have offered a small contribution to the ever-growing literature on COVID-19 and to have given a basis for further academic research into this phenomenon. We hope to have also provided organisations with ideas for actions they can take and lessons they can learn while dealing with the COVID-19 pandemic.

This type of discovery-oriented research which has been conducted in a short period of time unavoidably has limitations. The first limitation regards the literature review; as the current literature on COVID-19 is rapidly growing, especially the professional one, our own review is almost outdated the moment is has been conducted. This means that there might be actions performed by organisations or described in the literature in the meantime which we have not included. Another limitation is obviously the number of participating organisations. We aimed at providing a first perspective on what organisations are currently doing to deal with COVID-19 and this was successful as we were able to secure the cooperation on short notice of 19 organisations. With 19 organisations in three countries generalisation should not be claimed on the basis of our research results, future research should aim for more participating organisations in multiple countries. Finally, we only interviewed one person per organisation. Interviewing more people would potentially yield more actions per organisation. Future research, which repeats our study, makes it possible to evaluate if any shifts have taken place in the mentioned actions, it could also point out how effective specific actions have been in helping the organisations deal with the pandemic in a positive way.

In this research, organisations could also be asked which actions they took and subsequently stopped or abandoned as they did not turn out to be effective. It could also be evaluated if the actions, and their effectiveness, differ per type of organisation and industry. It would also be interesting to evaluate how organisation obtains the information on which actions to take: do they get this from the literature or from colleague organisations or trade associations, and with which speed. All this new research will give organisations a more robust basis on which to prepare themselves for the inevitable next crisis.

International Journal of Management and Applied Research, 2021, Vol. 8, No. 1 


\section{References}

1. Beech, N. and Anseel, F. (2020), "COVID-19 and Its Impact on Management Research and Education: Threats, Opportunities and a Manifesto", British Journal of Management, Vol. 31, No. 3, pp. 447-449. https://doi.org/10.1111/14678551.12421

2. Business.gov.nl (2020), The coronavirus and your company: Dutch government measures to help businesses, Netherlands Chamber of Commerce, available from: https://business.gov.nl/corona/overview/the-coronavirus-and-your-company/ [Accessed on 20 April 2021].

3. Bowers, M. R.; J.R. Hall and Srinivasan, M.M. (2017), "Organizational culture and leadership style: The missing combination for selecting the right leader for effective crisis management", Business Horizons, Vol. 60, No. 4, pp. 551-563. https://doi.org/10.1016/j.bushor.2017.04.001

4. Brahmbhatt, M. and Dutta, A. (2008), On SARS type economic effects during infectious disease outbreaks: Policy Research Working Paper 4466, Washington DC: The World Bank, https://doi.org/10.1596/1813-9450-4466

5. Brammer, S. and Clark, T. (2020), "COVID-19 and Management Education: Reflections on Challenges, Opportunities, and Potential Futures", British Journal of Management, Vol. 31, No. 3, pp. 453-456. https://doi.org/10.1111/14678551.12425

6. Burkle, F. M. (2010), "Do Pandemic Preparedness Planning Systems Ignore Critical Community and Local-Level Operational Challenges?", Disaster Medicine and Public Health Preparedness, Vol. 4, No. 1, pp. 24-29. https://doi.org/10.1097/dmp.0b013e3181cb4193

7. Cambridge Dictionary (2020), Disruptor, [Online] Available from: https://dictionary.cambridge.org/dictionary/english/disruptor?q=disruptors [Accessed 20 July 2020].

8. Cassidy, J. (2020), "An Economic-History Lesson for Dealing with the Coronavirus", New Yorker, [Online] Available from: https://www.newyorker.com/news/our-columnists/an-economic-history-lesson-fordealingwith-the-coronavirus [Accessed 20 July 2020].

9. Corbin, J. and Strauss, A. (2014), Basics of qualitative research: Techniques and procedures for developing grounded theory, $4^{\text {th }}$ ed., Thousand Oaks, CA: Sage Publications.

10. Cortez, R.M. and Johnston, W.J. (2020), "The Coronavirus crisis in B2B settings: Crisis uniqueness and managerial implications based on social exchange theory", Industrial Marketing Management, Vol. 88, pp. 125-135. https://doi.org/10.1016/j.indmarman.2020.05.004

11. de Smet, A., D. Pacthod, C. Relyea and Sternfels, B. (2020), Ready, set, go: Reinventing the organization for speed in the post-COVID-19 era, McKinsey \& Company [Online] Available from: https://www.mckinsey.com/business- 
functions/organization/our-insights/ready-set-go-reinventing-the-organization-forspeed-in-the-post-covid-19-era [Accessed 20 July 2020].

12. de Waal, A. and Linthorst, J. (2020), "Future-proofing the high-performing organization", Sustainability, Vol. 12, No. 20, 8507 https://doi.org/10.3390/su12208507

13. Eggers, F. (2020), "Masters of disasters? Challenges and opportunities for SMEs in times of crisis", Journal of Business Research, Vol. 116, pp. 199-208. https://doi.org/10.1016/j.jbusres.2020.05.025

14. Emmett, J., G. Schrah, M. Schrimper and Wood, A. (2020), COVID-19 and the employee experience: How leaders can seize the moment, McKinsey \& Company. [Online] Available from: https://www.mckinsey.com/businessfunctions/organization/our-insights/covid-19-and-the-employee-experience-howleaders-can-seize-the-moment [Accessed 20 July 2020].

15. Geoffard, P.Y. and Philipson, T. (1996), "Rational epidemics and their public control", International Economic Review, Vol. 37, No. 3, pp. 603-624. https://doi.org/10.2307/2527443

16. Gersovitz, M. and Hammer, J.S. (2004), "The economical control of infectious diseases", The Economic Journal, Vol. 114, No. 492, pp. 1-27. https://doi.org/10.1046/j.0013-0133.2003.0174.x

17. Grint, K. (2020), "Leadership, management and command in the time of the Coronavirus", Leadership, Vol. 16, No. 3, pp. 314-319. https://doi.org/10.1177/1742715020922445

18. He, H and Harris, L. (2020), "The impact of Covid-19 pandemic on corporate social responsibility and marketing philosophy", Journal of Business Research, Vol. 116, pp. 176-182. https://doi.org/10.1016/j.jbusres.2020.05.030

19. Herlant, M. (2020), How to lead your business through the Covid-19 crisis and its aftermath, Ernst \& Young [Online] Available from: https://www.ey.com/en be/strategy-transactions/how-to-lead-your-companythrough-the-covid-19-crisis-and-its-aftermath [Accessed 20 July 2020].

20. Hughes, P., R.E. Morgan, I.R. Hodgkinson, Kouropalatisb, Y. and Lindgreen, A. (2020), "A diagnostic tool to determine a strategic improvisation Readiness Index Score (IRIS) to survive, adapt, and thrive in a crisis", Industrial Marketing $\begin{array}{llll}\text { Management, } & \text { Vol. } & 88, & \text { pp. }\end{array}$ https://doi.org/10.1016/j.indmarman.2020.05.020

21. International Monetary Fund (2020), The IMF and Covid-19, [Online] Available from: https://www.imf.org/en/Topics/imf-and-covid19 [Accessed on 19 July 2020].

22. Jacobides, M. G. and Reeves, M. (2020), "Adapt Your Business to the New Reality: Start by understanding how habits have changed", Harvard Business Review, Vol. 98, No, 5, pp. 74-81.

23. Jacobson, N., D. Butterill and Goering, P. (2005), "Consulting as a Strategy for Knowledge Transfer", The Milbank Quarterly, Vol. 83, No. 2, pp. 299-321. https://doi.org/10.1111/j.1468-0009.2005.00348.x

International Journal of Management and Applied Research, 2021, Vol. 8, No. 1 
24. Kakabadse, N.K., E. Louchart and Kakabadse, A. (2020), "Consultant's role: A qualitative inquiry from the consultant's perspective", Journal of Management Development, Vol. 25, No. 5, pp. 416-500. https://doi.org/10.1108/02621710610666268

25. Kniffin, K.M.; Kniffin, K. M.; Narayanan, J.; Anseel, F.; Antonakis, J.; Ashford, S. P.; Bakker, A. B.; Bamberger, P.; Bapuji, H.; Bhave, D.P.; Choi, V.K.; Creary, S.J.; Demerouti, E.; Flynn, F.J.; Gelfand, M.J.; Greer, L.L.; Johns, G.; Kesebir, S. Klein, P.G.; Ozcelik, H.; Lee, S. Y.; Petriglieri, J. L.; Rothbard, N. P.; Rudolph, C. W.; Shaw, J. D.; Sirola, N.; Wanberg, C. R.; Whillans, A.; Wilmot, M.P. and van Vugt, M. (2020), "COVID-19 in the Workplace: Implications, issues, and insights for future research and action", American Psychologist, Vol. 76, No. 1, pp. 63-77. https://doi.org/10.1037/amp0000716

26. Levy, C., J. C. Mieszala, M. Mysore and Samandari, H. (2020), Coronavirus: 15 emerging themes for boards and executive teams, McKinsey \& Company [Online] Available from: https://www.mckinsey.com/business-functions/risk/ourinsights/coronavirus-15-emerging-themes-for-boards-and-executive-teams [Accessed 19 July 2020].

27. Linthorst, J. and de Waal, A. (2020), "Megatrends and Disruptors and Their Postulated Impact on Organizations", Sustainability, Vol. 12, No. 20, 8740. https://doi.org/10.3390/su12208740

28. Liu, Y.; Lee, J.M. and Lee, C. (2020), "The challenges and opportunities of a global health crisis: the management and business implications of COVID-19 from an Asian perspective", Asian Business \& Management, 19, 3, pp. 277-297. https://doi.org/10.1057/s41291-020-00119-x

29. Luijs, J., L. Engelen and L. Petten (2020), After the shock: learning to thrive in a (post) COVID-19 world - Beyond the crisis, Deloitte Netherlands, [Online] Available from: https://www2.deloitte.com/nl/nl/pages/strategy-analytics-andma/articles/after-the-shock-learning-to-thrive-in-a-post-covid-19-world.html [Accessed 19 July 2020].

30. Mahlendorf, M. D. (2014), "Discussion of: The Multiple Roles of the Finance Organization: Determinants, Effectiveness, and the Moderating Influence of Information System Integration", Journal of Management Accounting Research, Vol. 26, No. 2, pp. 33-42. https://doi.org/10.2308/jmar-10407

31. McConnell, P. (2020), "Planning For a Pandemic", ITNOW, Vol. 62, No. 2, pp. 18-21, https://doi.org/10.1093/itnow/bwaa038

32. McMenamin, J. P. (2009), "Pandemic Influenza: Is There a Corporate Duty to Prepare", Food and Drug Law Journal, Vol. 64, No. 1 pp., 69-100.

33. Naisbitt, J. and Aburdene, P. (1990), Megatrends 2000: ten new directions for the 1990's, New York: Morrow.

34. Saliola, F. and Islam, A. M. (2020), "How to Harness the Digital Transformation of the Covid Era", Harvard Business Review Digital Articles, pp. 2-5.

35. Shankar, K. (2020), "The Impact of COVID-19 on IT Services Industry - Expected Transformations", British Journal of Management, Vol. 31, No. 3, pp. 450-452. https://doi.org/10.1111/1467-8551.12423

International Journal of Management and Applied Research, 2021, Vol. 8, No. 1 
36. Shih, W. C. (2020), "Global Supply Chains in a Post-Pandemic World", Harvard Business Review, Vol. 98, No. 5, pp. 82-89.

37. Society for Human Resource Management (SHRM) (2020), COVID-19 Research: how the pandemic is challenging and changing employers, SHRM research report, [Online] Available from: https://shrm.org/hr-today/trends-andforecasting/research-andsurveys/Documents/SHRM\%20CV19\%20Research\%20Presentation\%20Release\% 202.pdf [Accessed 19 July 2020].

38. Statistics Netherlands (2020), Economic impact of COVID-19, [Online] Available from: https://www.cbs.nl/en-gb/dossier/coronavirus-crisis-cbs-figures/economicimpact-of-covid-19 [Accessed July 20, 2020].

39. Tourish, D. (2020), "Introduction to the special issue: Why the coronavirus crisis is also a crisis of leadership", Leadership, Vol. 16, No. 3, pp. 261-272. https://doi.org/10.1177/1742715020929242

40. Verbeke, A. (2020), "Will the COVID-19 Pandemic Really Change the Governance of Global Value Chains?", British Journal of Management, Vol. 31, No. 3, pp. 444-446. https://doi.org/10.1111/1467-8551.12422

41. Wang, Y., A. Hong, X, Li, and Gao, J. (2020). 'Marketing innovations during a global crisis: A study of China firms' response to COVID-19', Journal of Business Research, Vol. 116, pp. 214-220. https://doi.org/10.1016/j.jbusres.2020.05.029

42. Watson, R., B. Ives and Piccoli, G. (2020), "Guest Editorial: Practice-Oriented Research Contributions in the COVID-19 Forged New Normal", MIS Quarterly Executive, Vol. 19, No. 2, pp. v-viii.

43. Yost, E. and Cheng Y. (2021), "Customers' risk perception and dine-out motivation during a pandemic: Insight for the restaurant industry", International Journal of Hospitality Management, Vol. 95, 102889, https://doi.org/10.1016/j.ijhm.2021.102889 


\section{Appendix 1}

This appendix provides the detailed results from both the literature review and the practical research.

Organisation information + financial consequences of COVID-19

This Table provides information on the participating organisations, and also lists the financial consequences (positive, negative, not too much effect) COVID-19 had for each organisation.

\begin{tabular}{|c|c|c|c|c|c|c|}
\hline Org & Industry & $\begin{array}{c}\text { No. of } \\
\text { employees }\end{array}$ & Country & Negative & Positive & $\begin{array}{l}\text { Neither (too) } \\
\text { negative nor } \\
\text { (too) positive }\end{array}$ \\
\hline $\mathrm{O} 1$ & Education & 70 & Netherlands & & & $X$ \\
\hline $\mathrm{O} 2$ & Food producing & 600 & Netherlands & & $X$ & \\
\hline $\mathrm{O} 3$ & $\begin{array}{l}\text { European } \\
\text { agency }\end{array}$ & 100 & Netherlands & $X$ & & \\
\hline $\mathrm{O} 4$ & Food (drinks) & 1000 & Spain & & & $X$ \\
\hline O5 & Health care & 600 & Netherlands & & & $X$ \\
\hline O6 & Health care & 1100 & Netherlands & & & $X$ \\
\hline O7 & Health care & 50 & Netherlands & $X$ & & \\
\hline O8 & ICT & 1100 & UK & & $X$ & \\
\hline O9 & ICT & 300 & Netherlands & & $X$ & \\
\hline $\mathrm{O} 10$ & ICT & 80 & UK & & $\mathrm{X}$ & \\
\hline $\mathrm{O} 11$ & OEM & 40 & Netherlands & & & $\mathrm{X}$ \\
\hline $\mathrm{O} 12$ & Media & 200 & Netherlands & $\mathrm{X}$ & & \\
\hline $\mathrm{O} 13$ & Automotive & 6000 & Netherlands & $\mathrm{X}$ & & \\
\hline $\mathrm{O} 14$ & Automotive & 800 & Netherlands & $\mathrm{X}$ & & \\
\hline 015 & Engineering & 700 & Spain & & & $X$ \\
\hline 016 & Manufacturing & 2500 & Spain & $\mathrm{X}$ & & \\
\hline $\mathrm{O} 17$ & Real estate & 200 & Netherlands & & & $X$ \\
\hline $\mathrm{O} 18$ & Real estate & 20 & Netherlands & $X$ & & \\
\hline O19 & R\&D & 1400 & Spain & & & X \\
\hline \multicolumn{4}{|c|}{ Number of organisations per financial consequence } & 7 & 4 & 8 \\
\hline
\end{tabular}

International Journal of Management and Applied Research, 2021, Vol. 8, No. 1 
Actions + outcomes + lessons learned

This Table list per action in which type of literature (academic and/or professional) it was found, which organisations applied the action, and how many organisations in total chose for this action.

\begin{tabular}{|c|c|c|c|c|}
\hline Actions & $\begin{array}{l}\text { Academic } \\
\text { literature }\end{array}$ & $\begin{array}{l}\text { Professional } \\
\text { literature }\end{array}$ & Organisations & Total \\
\hline $\begin{array}{l}\text { Accelerate digital } \\
\text { transformation/Invest more in IT }\end{array}$ & $x$ & $x$ & $6,14,15,17,18,19$ & 6 \\
\hline Change the sourcing process & & $X$ & 15,19 & 2 \\
\hline $\begin{array}{l}\text { Create a greater organizational } \\
\text { capacity for } \\
\text { resilience/responsiveness }\end{array}$ & $\mathrm{X}$ & & $3,11,13,16$ & 4 \\
\hline $\begin{array}{l}\text { Develop effective remote } \\
\text { working/WFH }\end{array}$ & & $\mathrm{X}$ & $\begin{array}{c}1,2,3,4,5,6,7,8,9 \\
10,11,12,13,14,15 \\
17,18,19\end{array}$ & 18 \\
\hline $\begin{array}{l}\text { Focus on increased } \\
\text { communication and dialogue, } \\
\text { with remote leadership }\end{array}$ & $\mathrm{X}$ & & $\begin{array}{c}1,2,3,4,7,8,9,10 \\
11,12,13,17\end{array}$ & 12 \\
\hline $\begin{array}{l}\text { Put more emphasis on social } \\
\text { responsibility }\end{array}$ & $\mathrm{X}$ & & & 0 \\
\hline $\begin{array}{l}\text { Pay (more) attention to the people } \\
\text { in the organisation }\end{array}$ & & $\mathrm{X}$ & $\begin{array}{c}1,2,3,4,8,9,10,11 \\
12,13,14,15,17,18 \\
19\end{array}$ & 15 \\
\hline $\begin{array}{l}\text { Rebuild operations speedily and } \\
\text { with more speed }\end{array}$ & & $\mathrm{X}$ & $\begin{array}{c}1,2,3,5,6,12,13 \\
14,17,18,19\end{array}$ & 11 \\
\hline $\begin{array}{l}\text { Rethink the future of the } \\
\text { organisation (incl. long-term } \\
\text { focus + risk management) }\end{array}$ & $X$ & $X$ & $1,10,16,18$ & 4 \\
\hline $\begin{array}{l}\text { Strengthen collaboration / } \\
\text { Transfer to networks \& teamwork }\end{array}$ & $\mathrm{X}$ & $\mathrm{X}$ & $5,6,10,19$ & 4 \\
\hline $\begin{array}{l}\text { Stay in close contact with } \\
\text { customers and partners }\end{array}$ & & & $\begin{array}{l}1,3,4,5,6,7,10,11 \\
12,13,14,15,16,18\end{array}$ & 15 \\
\hline Take financial measures & & & $\begin{array}{c}1,3,11,12,13,14 \\
16,18\end{array}$ & 8 \\
\hline
\end{tabular}

This Table lists the positive outcomes and the lessons learned which were uncovered during the research and indicates which organisations, and how many organisations in total experienced, these.

\begin{tabular}{lcc}
\hline Positive outcomes of COVID-19 for the organisation & Organisations & Total \\
\hline $\begin{array}{l}\text { Better and more integrated organisational communication } \\
\text { Breaching of organisational hierarchy and willingness to } \\
\text { change old working patterns }\end{array}$ & $5,17,14,16,17,19$ & 2 \\
$\begin{array}{l}\text { Development of the right mindset for 'the new normal' } \\
\text { becoming the normal }\end{array}$ & $2,7,8$ & 3 \\
$\begin{array}{l}\text { Increased speed/flexibility/decisiveness/efficiency of work } \\
\text { More attention for and thinking about the 'bigger picture' }\end{array}$ & $3,4,5,6,8,17,18$ & 7 \\
$\begin{array}{l}\text { and future of the organisation } \\
\text { More trust of managers in employees and vice versa }\end{array}$ & $1,4,14,16,12,18,19$ & 3 \\
\hline
\end{tabular}

International Journal of Management and Applied Research, 2021, Vol. 8, No. 1 
More working from home

Opportunity to take ecological measures (f.i. less travel)

People becoming more self-sufficient/efficient, taking accountability, having a can-do attitude

People showing more solidarity/commitment/collaboration

Strengthened relations with clients and partners

Strengthening of the innovative culture / opportunity to develop new products and services

\section{Lessons learned}

As a company stay true to your values

Be prepared for a crisis ("fail to plain is plan to fail")

Communicate, communicate, communicate

Quickly develop new policies on the way the organisation is going to work

Virtual communication shortens lines and increases quality

of communication

Forget yearly targets and plans, survival and agility of the organisation is most important

Keep giving each other compliments

Maintain a highly visible leadership style

Make sure the organisation is agile enough to easily adapt to changes

Blended processes ( $=$ in-house + remote) are also effective

Need for employee involvement is an important drive for creative solutions

Sense of urgency makes things possible, so after COVID-19 keep creating this sense

Tailor organisational policies/procedures/resources more to the individual's situation

Understand the IT architecture and its

possibilities/usabilities

Watch out as management to get bogged down in operations at the expense of strategy

Have an eye for the issues regarding WFM (f.i. work/life balance, social aspects)

$\begin{array}{cc}3,4,6,9,12,13,15,17, & 10 \\ 18,19 & 6 \\ 2,6,8,12,14,19 & 4 \\ 1,8,11,15 & \\ 2,4,5,6,7,11,13,14, & 9 \\ 17 & 2 \\ 4,10 & 6\end{array}$

\section{Organisations}

Total

10

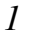

$10,11.15$

4, 17

6,18

2

$1,2,3,16,18 \quad 5$

11

10

1

$3,4,7,13,19$

5

$1,6,7,11,14,17,18 \quad 7$

$3,6,12$

3

2,4

2

15,17

2

$1,7,8,14,18$

5

11

12,13

10

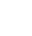

.

1

1

